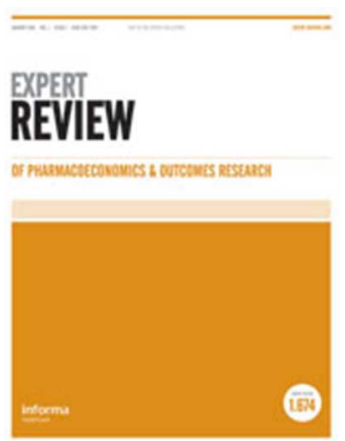

\title{
Economic evaluation alongside factorial trials: a systematic review of empirical studies
}

\begin{tabular}{|r|l|}
\hline Journal: & Expert Review of Pharmacoeconomics \& Outcomes Research \\
\hline Manuscript ID: & ERP-2015-0046.R2 \\
\hline Manuscript Type: & Reviews \\
\hline Keywords: & $\begin{array}{l}\text { cost-benefit, cost-utility analysis, Factorial design, economic evaluation, } \\
\text { Factorial trial }\end{array}$ \\
\hline \multicolumn{2}{|r}{} \\
\hline
\end{tabular}

\section{SCHOLARONE}

Manuscripts 
Table 1: Search strategies used

\begin{tabular}{|c|c|c|}
\hline DATABASE SEARCHED & TIMESPAN & SEARCH STRATEGY \\
\hline NHS EED & All years & (economic evaluation*) and (factorial design*) \\
\hline Embase & 1974 to 2013 July 30 & $\begin{array}{l}\text { 1. "cost"/ or cost-utility analysis.mp. or "cost benefit analysis"/ or "health care } \\
\text { cost"/ } \\
\text { or "quality of life"/ (442989) } \\
\text { 2. cost-effective\$.mp. (140957) } \\
\text { 3. economic evaluation\$.mp. (13687) } \\
\text { 4. } 1 \text { or } 2 \text { or } 3 \text { (544342) } \\
\text { 5. factorial design\$.mp. (1111) } \\
\text { 6. } 4 \text { and } 5 \text { (39) }\end{array}$ \\
\hline EconLit & All years & $\begin{array}{ll}\text { S1 } & \text { economic evaluation* } \\
\text { S2 } & \text { cost-utility analysis } \\
\text { S3 } & \text { cost-benefit analysis } \\
\text { S4 } & \text { cost-effective* } \\
\text { S5 } & \text { S1 OR S2 OR S3 OR S4 } \\
\text { S6 } & \text { factorial design* } \\
\text { S7 } & \text { S5 AND S6 }\end{array}$ \\
\hline COCHRANE & All years & $\begin{array}{ll}\# 1 & \text { economic evaluation* } \\
\# 2 & \text { factorial trial* } \\
\# 3 & \# 1 \text { and } \# 2\end{array}$ \\
\hline Science Citation Index (Expanded) & All years & (Factorial trial*) and (economic evaluation*) \\
\hline Conference proceedings citation & All years & (Factorial trial*) and (economic evaluation*) \\
\hline Ovid MEDLINE(R) & 1946 to July Week 32013 & 1. Quality-Adjusted Life Years/ or Cost-Benefit Analysis/ or Health Care Costs/ \\
\hline
\end{tabular}




\begin{tabular}{|l|l|l|}
\hline & & $\begin{array}{l}\text { or } \\
\text { cost-utility analysis.mp. or "Quality of Life"/ (194798) } \\
\text { 2. cost-effective\$.mp. (70146) } \\
\text { 3. economic evaluation\$.mp. (6062) } \\
\text { 4. 1 or 2 or 3 (236930) } \\
\text { 5. factorial design\$.mp. (961) } \\
6.4 \text { and 5 (30) }\end{array}$ \\
\hline BioMed Central & & (Factorial trial*) and (economic evaluation*) \\
\hline
\end{tabular}


Table 2: Summary of the studies used in the review

\begin{tabular}{|c|c|c|c|c|c|c|c|c|c|c|c|c|}
\hline & $\begin{array}{l}\text { AUTHOR(S) } \\
\text { AND YEAR } \\
\text { OF } \\
\text { PUBLICATI } \\
\text { ON }\end{array}$ & $\begin{array}{l}\text { TYPE OF } \\
\text { FACTORI } \\
\text { AL TRIAL }\end{array}$ & $\begin{array}{l}\text { TIME } \\
\text { HORIZON } \\
\text { OF THE } \\
\text { RESEARC } \\
\text { H }\end{array}$ & $\begin{array}{l}\text { OBJECTIVE( } \\
\text { S) OF THE } \\
\text { RESEARCH } \\
\end{array}$ & $\begin{array}{l}\text { TYPE OF } \\
\text { ECONOMIC } \\
\text { EVALUATI } \\
\text { ON }\end{array}$ & $\begin{array}{l}\text { PERSPECTI } \\
\text { VE }\end{array}$ & $\begin{array}{l}\text { SAMPL } \\
\text { E SIZE }\end{array}$ & $\begin{array}{l}\text { CONTRO } \\
\text { L } \\
\text { GROUP } \\
\text { USED }\end{array}$ & $\begin{array}{l}\text { PRIMARY } \\
\text { OUTCOME( } \\
\text { S) }\end{array}$ & $\begin{array}{l}\text { SENSITIVIT } \\
\text { Y ANALYSIS } \\
\text { UNDERTAK } \\
\text { EN }\end{array}$ & $\begin{array}{l}\text { METHOD OF } \\
\text { ANALYSIS AND } \\
\text { ITS } \\
\text { APPROPRITENE } \\
\text { SS TO THE } \\
\text { RESEARCH } \\
\text { OBJECTIVES } \\
\end{array}$ & $\begin{array}{l}\text { CONSIDERED } \\
\text { INTERACTIO } \\
\text { NS IN } \\
\text { ECONOMIC } \\
\text { OUTCOMES }\end{array}$ \\
\hline 1 & $\begin{array}{l}\text { Dangour et al., } \\
2011\end{array}$ & $2 \times 2$ & $\begin{array}{l}\text { Two (2) } \\
\text { years. }\end{array}$ & $\begin{array}{l}\text { The } \\
\text { objective(s) of } \\
\text { the research } \\
\text { was to assess } \\
\text { the } \\
\text { effectiveness } \\
\text { and cost- } \\
\text { effectiveness } \\
\text { of the Chilean } \\
\text { national } \\
\text { nutritional } \\
\text { supplementatio } \\
\text { n program on } \\
\text { decreasing the } \\
\text { incidence of } \\
\text { pneumonia and } \\
\text { a training } \\
\text { exercise } \\
\text { program to } \\
\text { increase } \\
\text { walking } \\
\text { capacity in } \\
\text { older people in } \\
\text { Santiago Chile. }\end{array}$ & $\begin{array}{l}\text { Cost- } \\
\text { effectiveness } \\
\text { analysis. }\end{array}$ & Societal & 2799 & Usual care & $\begin{array}{l}\text { Cost/unit } \\
\text { effect }\end{array}$ & Not stated. & $\begin{array}{l}\text { At-the-margins } \\
\text { analysis }\end{array}$ & No \\
\hline 2 & $\begin{array}{l}\text { The UK } \\
\text { BEAM trial } \\
\text { team, } 2004\end{array}$ & $2 \times 2$ & $\begin{array}{l}\text { One (1) } \\
\text { year }\end{array}$ & $\begin{array}{l}\text { The objective } \\
\text { of the research } \\
\text { was to assess } \\
\text { the cost- } \\
\text { effectiveness } \\
\text { of adding } \\
\text { spinal } \\
\text { manipulation, } \\
\text { exercise or a } \\
\text { combination of } \\
\text { the treatments } \\
\text { to "best care" } \\
\text { for patients }\end{array}$ & $\begin{array}{l}\text { Cost-utility } \\
\text { analysis }\end{array}$ & Health service & 1287 & placebo & cost/QALY & $\begin{array}{l}\text { One-way } \\
\text { sensitivity } \\
\text { analysis for } \\
\text { three different } \\
\text { scenarios. }\end{array}$ & $\begin{array}{l}\text { Within-the-table } \\
\text { analysis }\end{array}$ & Yes \\
\hline
\end{tabular}




\begin{tabular}{|c|c|c|c|c|c|c|c|c|c|c|c|c|}
\hline & & & & $\begin{array}{l}\text { consulting with } \\
\text { low back pain. }\end{array}$ & & & & & & & & \\
\hline 3 & $\begin{array}{l}\text { Barton et al., } \\
2009\end{array}$ & $2 \times 2$ & $\begin{array}{l}\text { Two (2) } \\
\text { years }\end{array}$ & $\begin{array}{l}\text { The objective } \\
\text { of the research } \\
\text { was to estimate } \\
\text { the cost- } \\
\text { effectiveness } \\
\text { of four } \\
\text { different } \\
\text { lifestyle } \\
\text { interventions } \\
\text { for knee pain }\end{array}$ & $\begin{array}{l}\text { Cost-utility } \\
\text { analysis }\end{array}$ & Health service & 389 & Usual care & Cost/QALY & $\begin{array}{l}\text { Probabilistic- } \\
\text { sensitivity } \\
\text { analysis. }\end{array}$ & $\begin{array}{l}\text { Within-the-table } \\
\text { analysis. }\end{array}$ & No \\
\hline 4 & $\begin{array}{l}\text { Jafar et al., } \\
2011\end{array}$ & $2 \times 2$ & $\begin{array}{l}\text { Two (2) } \\
\text { years }\end{array}$ & $\begin{array}{l}\text { The objective } \\
\text { of the research } \\
\text { was to assess } \\
\text { the cost- } \\
\text { effectiveness } \\
\text { of Home } \\
\text { Health } \\
\text { Education } \\
\text { (HHE) } \\
\text { and/special } \\
\text { training of GPs } \\
\text { on the blood } \\
\text { pressure levels } \\
\text { of adults aged } \\
\text { 40yrs or above } \\
\text { with } \\
\text { hypertension }\end{array}$ & $\begin{array}{l}\text { Cost-utility } \\
\text { analysis }\end{array}$ & Societal & 1341 & placebo & cost/DALY & $\begin{array}{l}\text { Probabilistic } \\
\text { sensitivity } \\
\text { analysis }\end{array}$ & $\begin{array}{l}\text { Within-the-table } \\
\text { analysis }\end{array}$ & No \\
\hline 5 & $\begin{array}{l}\text { Pinto et al., } \\
2013\end{array}$ & $2 \times 2$ & $\begin{array}{l}\text { One (1) } \\
\text { year }\end{array}$ & $\begin{array}{l}\text { The objective } \\
\text { of the trial was } \\
\text { to evaluate the } \\
\text { cost- } \\
\text { effectiveness } \\
\text { of manual } \\
\text { physiotherapy, } \\
\text { exercise } \\
\text { physiotherapy }\end{array}$ & $\begin{array}{l}\text { Cost-utility } \\
\text { analysis. }\end{array}$ & $\begin{array}{l}\text { Health service } \\
\text { and societal }\end{array}$ & 206 & placebo & Cost/QALY & $\begin{array}{l}\text { One-way } \\
\text { sensitivity } \\
\text { analysis }\end{array}$ & $\begin{array}{l}\text { Within-the-table } \\
\text { analysis }\end{array}$ & No \\
\hline
\end{tabular}




\begin{tabular}{|c|c|c|c|c|c|c|c|c|c|c|c|c|}
\hline & & & & $\begin{array}{l}\text { and a } \\
\text { combination of } \\
\text { the two for } \\
\text { patients with } \\
\text { osteoarthritis } \\
\text { of the hip or } \\
\text { knee }\end{array}$ & & & & & & & & \\
\hline 6 & $\begin{array}{l}\text { Morris et al., } \\
2011\end{array}$ & $2 \times 2$ & $\begin{array}{l}\text { One (1) } \\
\text { year }\end{array}$ & $\begin{array}{l}\text { The objective } \\
\text { of the research } \\
\text { was to assess } \\
\text { the cost } \\
\text { effectiveness } \\
\text { of a } \\
\text { rehabilitation } \\
\text { program and } \\
\text { educational } \\
\text { booklet each } \\
\text { compared with } \\
\text { usual care for } \\
\text { the post- } \\
\text { operative } \\
\text { management of } \\
\text { patients } \\
\text { undergoing } \\
\text { surgery }\end{array}$ & $\begin{array}{l}\text { Cost-utility } \\
\text { analysis }\end{array}$ & $\begin{array}{l}\text { Health service } \\
\text { and societal }\end{array}$ & 338 & placebo & cost/QALY & $\begin{array}{l}\text { nonparametric } \\
\text { bootstrapping }\end{array}$ & $\begin{array}{l}\text { At-the-margins } \\
\text { analysis }\end{array}$ & No \\
\hline 7 & $\begin{array}{l}\text { Thomas et al., } \\
2005\end{array}$ & $2 \times 2$ & $\begin{array}{l}\text { Two (2) } \\
\text { years }\end{array}$ & $\begin{array}{l}\text { The objective } \\
\text { was to } \\
\text { compare the } \\
\text { cost- } \\
\text { effectiveness } \\
\text { of exercise and } \\
\text { monthly } \\
\text { telephone } \\
\text { support for the } \\
\text { treatment of } \\
\text { knee pain. }\end{array}$ & $\begin{array}{l}\text { Cost- } \\
\text { effectiveness } \\
\text { analysis }\end{array}$ & $\begin{array}{l}\text { Health service } \\
\text { perspective }\end{array}$ & 786 & Usual care & $\begin{array}{l}\text { Cost/unit } \\
\text { effect }\end{array}$ & $\begin{array}{l}\text { nonparametric } \\
\text { bootstrapping }\end{array}$ & $\begin{array}{l}\text { At-the-margins } \\
\text { analysis }\end{array}$ & No \\
\hline 8 & $\begin{array}{l}\text { Campbell et } \\
\text { al., } 2005\end{array}$ & $2 \times 2$ & $\begin{array}{l}\text { One (1) } \\
\text { year }\end{array}$ & $\begin{array}{l}\text { To assess the } \\
\text { efficacy and } \\
\text { cost- } \\
\text { effectiveness } \\
\text { of a home } \\
\text { safety program } \\
\text { and a home } \\
\text { exercise }\end{array}$ & $\begin{array}{l}\text { Cost- } \\
\text { effectiveness } \\
\text { analysis }\end{array}$ & societal & 391 & $\begin{array}{l}\text { Usual } \\
\text { care }\end{array}$ & $\begin{array}{l}\text { Cost/unit } \\
\text { effect }\end{array}$ & $\begin{array}{l}\text { one-way } \\
\text { sensitivity } \\
\text { analysis }\end{array}$ & $\begin{array}{l}\text { At-the-margins } \\
\text { analysis }\end{array}$ & No \\
\hline
\end{tabular}




\begin{tabular}{|c|c|c|c|c|c|c|c|c|c|c|c|c|}
\hline & & & & $\begin{array}{l}\text { program to } \\
\text { reduce falls } \\
\text { and injuries in } \\
\text { older people } \\
\text { with low } \\
\text { vision. }\end{array}$ & & & & & & & & \\
\hline 9 & $\begin{array}{l}\text { Lindgren et al., } \\
2009\end{array}$ & $2 \times 2$ & $\begin{array}{l}\text { Three (3) } \\
\text { years }\end{array}$ & $\begin{array}{l}\text { To assess the } \\
\text { cost } \\
\text { effectiveness } \\
\text { of four } \\
\text { alternative } \\
\text { treatment } \\
\text { strategies } \\
\text { in patients with } \\
\text { hypertension } \\
\text { and three or } \\
\text { more } \\
\text { cardiovascular } \\
\text { risk } \\
\text { factors in the } \\
\text { UK }\end{array}$ & $\begin{array}{l}\text { Cost-utility } \\
\text { analysis }\end{array}$ & $\begin{array}{l}\text { Health service } \\
\text { and societal } \\
\text { perspectives }\end{array}$ & 19,257 & $\begin{array}{l}\text { Usual } \\
\text { care }\end{array}$ & Cost/QALY & $\begin{array}{l}\text { One-way } \\
\text { sensitivity } \\
\text { analysis and } \\
\text { probabilistic } \\
\text { sensitivity } \\
\text { analysis }\end{array}$ & $\begin{array}{l}\text { Within-the table } \\
\text { analysis }\end{array}$ & No \\
\hline $\begin{array}{l}1 \\
0\end{array}$ & $\begin{array}{l}\text { Effing et al., } \\
2009\end{array}$ & $2 \times 2$ & $\begin{array}{l}\text { One (1) } \\
\text { year }\end{array}$ & $\begin{array}{l}\text { To assess the } \\
\text { Cost- } \\
\text { effectiveness } \\
\text { of self- } \\
\text { treatment of } \\
\text { exacerbations } \\
\text { on the severity } \\
\text { of } \\
\text { exacerbations } \\
\text { in } \\
\text { patients with } \\
\text { COPD }\end{array}$ & $\begin{array}{l}\text { Cost- } \\
\text { effectiveness } \\
\text { analysis }\end{array}$ & Health service & 142 & $\begin{array}{l}\text { Usual } \\
\text { care }\end{array}$ & $\begin{array}{l}\text { Cost/unit } \\
\text { effect }\end{array}$ & $\begin{array}{l}\text { Probabilistic } \\
\text { sensitivity } \\
\text { analysis }\end{array}$ & At-the-margins & No \\
\hline $\begin{array}{l}1 \\
1\end{array}$ & $\begin{array}{l}\text { Lewca et al., } \\
2013\end{array}$ & $2 \times 2$ & $\begin{array}{l}\text { Five (5) } \\
\text { years }\end{array}$ & $\begin{array}{l}\text { To assess the } \\
\text { Effects and } \\
\text { cost- } \\
\text { effectiveness } \\
\text { of community } \\
\text { mobilisation } \\
\text { through } \\
\text { women's } \\
\text { groups, and } \\
\text { health } \\
\text { education } \\
\text { through female } \\
\text { volunteer } \\
\text { peer } \\
\text { counsellors on }\end{array}$ & $\begin{array}{l}\text { Cost- } \\
\text { effectiveness } \\
\text { analysis }\end{array}$ & Health service & 185888 & placebo & $\begin{array}{l}\text { Cost/unit } \\
\text { effect }\end{array}$ & Not stated & $\begin{array}{l}\text { Within-the-table } \\
\text { analysis }\end{array}$ & No \\
\hline
\end{tabular}




\begin{tabular}{|c|c|c|c|c|c|c|c|c|c|c|c|c|}
\hline & & & & $\begin{array}{l}\text { rates of infant } \\
\text { care, feeding, } \\
\text { morbidity, and } \\
\text { mortality. }\end{array}$ & & & & & & & & \\
\hline $\begin{array}{l}1 \\
2\end{array}$ & $\begin{array}{l}\text { Hollinghurst et } \\
\text { al., } 2008\end{array}$ & $4 \times 2$ & $\begin{array}{l}\text { One (1) } \\
\text { year }\end{array}$ & $\begin{array}{l}\text { An economic } \\
\text { evaluation of } \\
\text { therapeutic } \\
\text { massage, } \\
\text { exercise, and } \\
\text { lessons in the } \\
\text { Alexander } \\
\text { technique for } \\
\text { treating } \\
\text { persistent back } \\
\text { pain }\end{array}$ & $\begin{array}{l}\text { Cost-utility } \\
\text { analysis and } \\
\text { cost- } \\
\text { consequence } \\
\text { analysis }\end{array}$ & $\begin{array}{l}\text { Health service, } \\
\text { societal and } \\
\text { patient }\end{array}$ & 579 & $\begin{array}{l}\text { Usual } \\
\text { care }\end{array}$ & Cost/QALY & $\begin{array}{l}\text { One-way } \\
\text { sensitivity } \\
\text { analysis and } \\
\text { non-parametric } \\
\text { bootstrapping }\end{array}$ & $\begin{array}{l}\text { Within-the-table } \\
\text { analysis }\end{array}$ & No \\
\hline $\begin{array}{l}\mathbf{1} \\
\mathbf{3}\end{array}$ & $\begin{array}{l}\text { Bakkhai et al., } \\
2003\end{array}$ & $2 \times 2$ & $\begin{array}{l}\text { One }(1) \\
\text { year }\end{array}$ & $\begin{array}{l}\text { To assess the } \\
\text { Cost- } \\
\text { Effectiveness } \\
\text { of Coronary } \\
\text { Stenting and } \\
\text { Abciximab for } \\
\text { Patients With } \\
\text { Acute } \\
\text { Myocardial } \\
\text { Infarction }\end{array}$ & $\begin{array}{l}\text { Cost-utility } \\
\text { analysis }\end{array}$ & Health service & 1703 & $\begin{array}{l}\text { Usual } \\
\text { care }\end{array}$ & Cost/QALY & $\begin{array}{l}\text { Non- } \\
\text { parametric } \\
\text { bootstrapping }\end{array}$ & $\begin{array}{l}\text { Within-the-table } \\
\text { analysis }\end{array}$ & No \\
\hline $\begin{array}{l}1 \\
4\end{array}$ & $\begin{array}{l}\text { Boyle et al., } \\
2007\end{array}$ & $2 \times 2$ & $\begin{array}{l}\text { One (1) } \\
\text { year }\end{array}$ & $\begin{array}{l}\text { To assess the } \\
\text { effect and } \\
\text { economic } \\
\text { evaluation of } \\
\text { direct versus } \\
\text { indirect and } \\
\text { individual } \\
\text { versus group } \\
\text { modes of } \\
\text { speech and } \\
\text { language } \\
\text { therapy } \\
\text { for children } \\
\text { with primary } \\
\text { language } \\
\text { impairment }\end{array}$ & $\begin{array}{l}\text { Cost- } \\
\text { effectiveness } \\
\text { analysis }\end{array}$ & patient & 161 & $\begin{array}{l}\text { Usual } \\
\text { care }\end{array}$ & $\begin{array}{l}\text { Cost/unit } \\
\text { effect }\end{array}$ & $\begin{array}{l}\text { Non- } \\
\text { parametric } \\
\text { bootstrapping }\end{array}$ & $\begin{array}{l}\text { Within-the-table } \\
\text { analysis }\end{array}$ & No \\
\hline $\begin{array}{l}1 \\
5\end{array}$ & $\begin{array}{l}\text { McBeth et al., } \\
2012\end{array}$ & $2 \times 2$ & $\begin{array}{l}\text { One }(1) \\
\text { year }\end{array}$ & $\begin{array}{l}\text { To assess the } \\
\text { cost- } \\
\text { effectiveness } \\
\text { of cognitive } \\
\text { behaviour } \\
\text { therapy, } \\
\text { Exercise, }\end{array}$ & $\begin{array}{l}\text { Cost-utility } \\
\text { analysis }\end{array}$ & Health service & 442 & $\begin{array}{l}\text { Usual } \\
\text { care }\end{array}$ & Cost/QALY & $\begin{array}{l}\text { Non- } \\
\text { parametric } \\
\text { bootstrapping }\end{array}$ & $\begin{array}{l}\text { Within-the-table } \\
\text { analysis }\end{array}$ & No \\
\hline
\end{tabular}




\begin{tabular}{|c|c|c|c|c|c|c|c|c|c|c|c|c|}
\hline & & & & $\begin{array}{l}\text { or both for } \\
\text { treating } \\
\text { chronic } \\
\text { widespread } \\
\text { pain }\end{array}$ & & & & & & & & \\
\hline $\begin{array}{l}1 \\
6\end{array}$ & $\begin{array}{l}\text { Waterhouse et } \\
\text { al., } 2010\end{array}$ & $2 \times 2$ & $\begin{array}{l}\text { One (1) } \\
\text { year }\end{array}$ & $\begin{array}{l}\text { To assess the } \\
\text { cost- } \\
\text { effectiveness } \\
\text { of community } \\
\text { versus hospital } \\
\text { pulmonary } \\
\text { rehabilitation } \\
\text { for chronic } \\
\text { obstructive } \\
\text { pulmonary } \\
\text { disease } \\
\text { followed by } \\
\text { telephone or } \\
\text { conventional } \\
\text { follow-up }\end{array}$ & $\begin{array}{l}\text { Cost-utility } \\
\text { analysis }\end{array}$ & Health service & 240 & $\begin{array}{l}\text { Usual } \\
\text { care }\end{array}$ & Cost/QALY & $\begin{array}{l}\text { Non- } \\
\text { parametric } \\
\text { bootstrapping }\end{array}$ & $\begin{array}{l}\text { Within-the-table } \\
\text { analysis }\end{array}$ & No \\
\hline
\end{tabular}

\section{Table 3: Summary of the main differences between the at-the-margins approach and the within-the-table approach}

\begin{tabular}{|l|l|}
\hline Within-the-table approach & At-the-margins approach \\
\hline All interventions within the trial are treated separately. E.g. in a 2x2 trial comparing interventions A, B, \\
AB and O all arms are treated separately & $\begin{array}{l}\text { Considers the trial as separate overlapping trials. E.g. in a 2x2 trial comparing A,B,AB and O, all } \\
\text { participants who received A (i.e. A and AB) are compared to those who did not receive A (i.e. B and O) }\end{array}$ \\
\hline $\begin{array}{l}\text { Takes interactions between interventions into account (i.e. assumes that the effects of intervention A are } \\
\text { influenced by the inclusion of intervention B and vice versa) }\end{array}$ & $\begin{array}{l}\text { Assumes independence of interventions (i.e. the effects of intervention A are not influenced by the } \\
\text { inclusion of intervention B and vice versa) }\end{array}$ \\
\hline The approach is less efficient (i.e. effects of treatments are not based on the entire sample size) & The approach is more efficient (i.e. treatment effects are based on the entire sample size) \\
\hline Estimates obtained are considered to be unbiased & Estimates obtained are considered to be biased if interactions are present \\
\hline
\end{tabular}


Figure 1: Summary of the search strategy

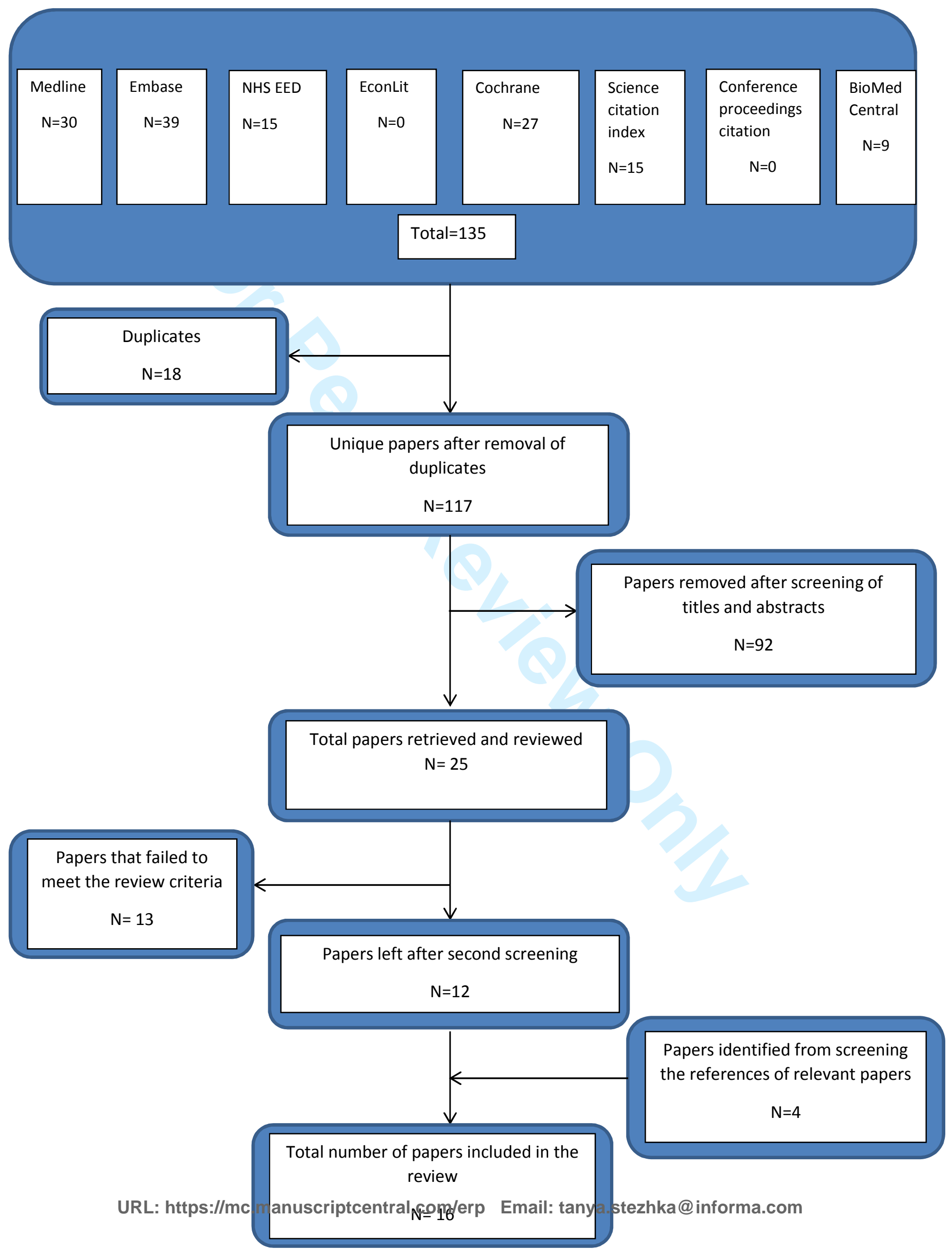




\title{
US English, ERP October, Review, 1 figure, 3 tables \\ Economic evaluation alongside factorial trials: a systematic review of empirical studies
}

\author{
Samuel N. Frempong, ${ }^{1}$ Ilias Goranitis, ${ }^{1}$ Raymond Oppong ${ }^{1,}$ \\ ${ }^{1}$ Health Economics Unit, School of Health and Population Sciences, University of Birmingham, Birmingham, \\ UK \\ Address for Correspondence: \\ Raymond Oppong \\ Health Economics Unit, \\ School of Health and Population Sciences, \\ University of Birmingham \\ B15 2TT, \\ UK. \\ Telephone: +44 (0) 1214147065 \\ Fax: +44 (0) 1214148969 \\ Email: r.a.oppong@bham.ac.uk
}

Financial \& Competing interests disclosure

The authors have no relevant affiliations or financial involvement with any organization or entity with a financial interest in or financial conflict with the subject matter or materials discussed in the manuscript. This includes employment, consultancies, honoraria, stock ownership or options, expert testimony, grants or patents received or pending, or royalties. 
Key words: cost-benefit analysis, cost-effectiveness, cost-utility analysis, economic evaluation, factorial design, factorial trial.

\begin{abstract}
Although economic evaluations have been carried out alongside factorial trials, there seems to be limited guidance/consensus on appropriate methods of analysis. Following Centre for Review and Dissemination guidance, a systematic review of published literature for all years was carried out to explore how economic evaluation alongside factorial trials have been conducted and only full economic evaluations conducted alongside factorial trials were included. A total of 16 relevant studies were identified and an assessment of these indicated that two methods: within-the-table and at-themargins approaches were used for the analysis. With the exception of one study, all others did not consider interactions in costs and outcomes or give a detailed explanation of why a particular approach was adopted. The authors recommend that additional guidance is needed and further research is required to evaluate the impact of alternative methods on policy recommendations and establish good practice methods for the economic analysis of factorial trials.

ABSTRACT
\end{abstract}




\section{INTRODUCTION}

Health economic evaluations are commonly used to inform resource allocation decisions in most industrialised nations and many funding bodies such as the UK National Institute for Health Research's Health Technology Assessment Programme now routinely request the assessment of costeffectiveness to be 'piggybacked' on Randomised Controlled Trials (RCT's) [1-3]. While there are several types of RCT's used in medical research, factorial trials are becoming more prevalent in a context where health care research budgets are increasingly constrained.

Factorial trials "test the effects of two or more interventions simultaneously using various combinations of the interventions within the same trial" [4]. There are several factorial designs, with the most common being the $2 \times 2$ which assesses two interventions with each one of them having two levels. For example, in a 2x2 factorial trial of self-management options for hand osteoarthritis, patients can be randomised to either of the following interventions: usual care, joint protection, hand exercises or a combined intervention (joint protection plus hand exercises). This allows for more information to be obtained in a single trial at a reduced overall cost [5]. In addition, factorial trials allow for the investigation of interactions between the treatments under scrutiny [6-7], and in the absence of interactions, they provide greater power than traditional multiple-arm trials of similar sample size evaluating the same interventions [8].

As a consequence, there is now a growing interest in employing these designs in trial-based economic evaluations [9]. However, unlike in the analysis of clinical outcomes, where the methods of analysis are well established, methods for the economic analysis of factorial trials remain unclear $[10,11]$. Recent research suggested that the appropriate analysis of factorial designs in economic evaluations is important, not only because interactions are more likely to occur in economic data but also because economic evaluations focus on the estimation of incremental cost-effectiveness ratios (ICERs) as opposed to hypothesis testing which is the main focus of clinical studies [10]. There is therefore a greater potential for bias which can affect the validity of results if the analysis is not carried out appropriately. In addition, this type of trial leads to a reduction in sample size if interactions are accounted for. This is problematic because most two arm trials are known to be underpowered for the 
economic analysis and as a consequence, the factorial trial could potentially lead to further uncertainty in economic outcomes [11]. Even though these challenges have been identified, there is still uncertainty about how to overcome them.

The objective of this study is to systematically review economic evaluations conducted alongside factorial trials with the aim of exploring the empirical methods involved and to offer recommendations that could potentially assist in the development of good practice guidelines in this context. To the best of our knowledge, no other study has conducted a systematic review of economic evaluations alongside factorial trials.

\section{METHODS}

A systematic review of economic evaluations alongside factorial trials was conducted following the guidelines outlined by the UK Centre for Review and Dissemination (CRD) [12]. In the absence of Medical Subject Heading (MeSH) for factorial trials and economic evaluations, search terms, including truncation where appropriate, included the terms "cost-benefit analysis", "cost-effectiveness analysis", "cost-utility analysis", "economic evaluation", "factorial design" and "factorial trial". The following electronic databases were searched for relevant studies published for all years: CENTRAL (Cochrane Wiley), MEDLINE (Ovid), EMBASE (Ovid), EconLit (EBSCO), NHS EED (Cochrane Wiley), Science Citation Index (ISI) and Conference Proceedings Citation Index (ISI). In addition to this, a methodological research in the Cochrane Methodology database (Cochrane Wiley) and BioMed Central portfolio of journals was also conducted. The final search strategies across the different databases are detailed in Table 1.

To be included in the review, studies had to be full economic evaluations conducted alongside a factorial trial. Studies were excluded if they were partial or non-economic evaluation studies, cohort studies, case-control studies, systematic reviews, study protocols or commentaries. Non-English studies and grey literature were also excluded.

Literature search was carried out between July and August 2013 in two stages. First, titles and abstracts were screened to identify potentially relevant papers. The second stage involved screening 
the full papers considered to be potentially relevant. The screening process in both stages was done against the inclusion and exclusion criteria. The reference lists of the papers identified after the second screening process were also screened for additional relevant papers. A quality assessment was not conducted because the focus of the review was to explore the methodologies that have been employed in practise for the economic analysis of factorial trials and not the validity of the estimates obtained from the included studies. Thus, all the relevant studies identified from the selection process were subsequently considered for data extraction. For each of the studies included in the review, data were extracted concerning the perspective of the study and type of economic evaluation, cost and outcomes considered and method of analysis of factorial trials.

\section{RESULTS}

The electronic database search identified 135 potentially relevant papers of which 18 were duplicates. Out of the 117 remaining papers, 92 were excluded after the screening of titles. A thorough assessment of the 25 papers identified to be potentially relevant led to the exclusion of a further 13 papers from the list, limiting the number of papers to 12 . The 13 papers were excluded for the following reasons; 7 of them were study protocols, 3 were systematic reviews and 3 were not full economic evaluations. The reference lists of the 12 relevant papers were also screened and this led to the identification of 4 additional papers. A total of 16 papers were therefore included in the review. Figure 1 shows a flow chart of the papers identified, retrieved and retained or excluded at each stage of the review process.

\section{Summary of selected studies}

As shown in table 2, the studies included in the review were published between 2003 and 2013. Of these, 15 were ' $2 \times 2$ ' trials and one was a ' $4 \times 2$ ' trial. The included studies were conducted across eight different countries: Chile [13], the UK [14-21], New Zealand [22, 23], Pakistan [24], Sweden [25], Netherlands [26], Malawi [27] and the USA [28]. Most studies were related to musculoskeletal disease (seven studies) or cardiovascular disease (five studies). 


\section{Perspectives and type of economic evaluation undertaken}

Studies were conducted from either a societal [13,23,24], a health service [14,15,17,20,21,26,27,28], or patient perspective [19]. Three studies considered both a health service and societal perspective $[16,22,25]$ and one considered all three [18]. In all the studies, the reason for adopting a particular perspective was given and this was appropriately followed for collecting the right cost data within the boundaries of the perspective adopted.

Two types of economic evaluations were mainly undertaken across the sixteen studies. These are costeffectiveness analysis (CEA) and cost-utility analysis (CUA) (Table 2). CEA was undertaken in six studies, [13,17,19,23,26,27] whereas CUA was undertaken in nine studies, [14-16,20-22,24,25,28] with one study undertaking both cost-consequence and cost-utility analysis [18]. All studies gave a justification of why they employed each economic evaluation technique and it was found to be appropriate to the research objectives. The sample size of most studies (approximately 63\%) was less than 800 participants. Only two studies recruited more than 3000 participants. The sample sizes were calculated to detect the clinical effects in all studies. Studies differed in terms of what constituted the control group for their research. Eleven studies $[13,15,17-21,23,25,26,28]$ used 'usual care' as the control group whereas five studies [14,16,22,24,27] used a placebo.

\section{Costs and outcomes}

Six studies had their primary outcome of interest reported in cost per unit effect $[13,17,19,23,26,27]$ whereas ten studies reported their primary outcomes in cost per Quality Adjusted Life Year (QALY) gained [14-16,18,20-22,25,28] or cost per Disability Adjusted Life Year (DALY) averted [24]. In terms of costing, all the studies adopted the ingredient approach (where estimates of total resource use are multiplied by their respective unit prices) to estimate the cost of the interventions. In all studies where the trials were conducted over a time horizon of one year, cost and QALYs were not discounted whereas in studies with larger time horizon costs and QALYs were discounted.

\section{Analytical approaches to the economic analysis of factorial trials}


Although not explicitly stated, two methods of analysis were identified across the studies; within-thetable approach $[14-15,18-20,22,24,25,27,28]$ and at-the-margins approach $[13,16,17,23,26]$. The within-the-table approach implicitly assumes that the interventions within the factorial design are mutually exclusive and therefore considers each of them as a separate treatment strategy allowing the effect of interactions to be easily seen [29]. The at-the-margins approach implicitly assumes that the interventions under investigation are independent and there is no interaction between treatments. The trial is therefore analysed as though it were overlapping arms of an RCT comparing the effects of treatments separately [29]. One study considered both methods and stated that the reason for employing both methods was to provide the most relevant information for policy makers (within-thetable approach) and to carry out the analysis in line with the convention for a factorial design (at-themargins approach) [18]. A summary of the characteristics of both approaches are presented in table 3 . It should be noted that apart from the choice of approach in the clinical study and the objective of the economic analysis, other factors such as sample size, disease area or comparator did not seem to have an influence on the choice of approach.

A thorough assessment of the studies reviewed indicated that, none of the studies tested interactions between treatments in terms of costs and outcomes nor gave a detailed explanation on how they were going to account for the factorial nature of the trial. The only instance where reference was made to interaction in cost was the study by The UK BEAM trial team [14], where they mentioned a comparison of four distinct treatments although cost showed no interaction between treatments. In all other instances where studies mentioned an interaction was to reiterate whether any statistically significant interaction was evident in clinical outcomes, which then informed the decision about which method of analysis to adopt rather than testing for interactions in the economic outcomes.

\section{DISCUSSION}

The literature search indicated that two methods (within-the-table and at-the-margins approach) are commonly used in the economic analysis of factorial trials. The choice of method was found to be mainly influenced by the method adopted in the clinical study. It is therefore apparent that for some of the studies, even though the clinical trial detected interactions, if the objective was to calculate the 
separate ICERs for the factors, at-the-margins approach was employed instead of the within-the-table approach and vice-versa [14].

None of the studies explored interactions between economic outcomes or stated the reasons why such interactions were not expected to occur. This is problematic as economic outcomes are different from the clinical ones, and thus special considerations should be given to their analysis. This may be due to a lack of clear guidance on how economic evaluations alongside factorial trials should be conducted and their methodological challenges.

One such challenge may relate to the sample size of the trial. In all studies, sample sizes used were calculated with the purpose of detecting the clinical effects of the interventions under scrutiny. The problem that arises here is that some trials may be inadequately powered to detect plausible clinical interactions $[7,30]$, and thus the absence of proof of evidence for interactions is equated to proof of absence of evidence for interactions in the clinical outcomes [30]. Given that interactions are more likely to occur in economic outcomes rather than the clinical [10] this assumption is likely to be invalid. Even when interactions in economic outcomes are identified, conducting the appropriate analysis within-the-table may result in further loss of power and greater uncertainty to the economic results.

It is also worth stating that, unlike clinical outcomes that are generally normally distributed, economic outcomes generally follow a skewed distribution and are associated with a higher variance, which impact on the way they should be analysed [31,32]. Therefore, even if the trial is adequately powered to detect the main difference in clinical outcome, it will be typically underpowered for the analysis of economic outcomes. But as can be seen from the sample sizes employed in the various trials, the issue of sample size in relation to the detection of interactions (in economic outcomes) and the use of appropriate sample size in relation to the distribution of the economic outcomes for their effective analysis were not appropriately taken into consideration by almost all the studies.

Only one study [18] employed both the at-the-margins and within-the-table approaches, and even though this study, like the rest, did not give an explicit explanation of how the factorial nature of the 
trial was accounted for when the economic variables were analysed, it may be argued that presenting both analyses is more informative, even when they result in contradicting recommendations. In terms of economic evaluation in general, there were consistencies with respect to the methodological and practical aspects. These consistencies can be attributed to the immense literature and guidelines available for methodologically robust economic evaluations. Hence researchers have a clear understanding and direction on how economic evaluations should be conducted and in most cases, if not all, follow it accordingly [33-37].

To the best of our knowledge, this is the first study to review economic evaluations conducted alongside factorial trials and therefore provides a description of the current state of play in the economic analysis of factorial trials. A possible limitation is the broad nature of the research question. This study was not limited to a particular disease area and it is quite possible that some studies might have been missed out. However, we made every effort to identify all relevant studies by developing the search strategy with advice from an information specialist.

The increasing pressures on health care and research budgets are likely to be associated with an increase in the use of factorial trials. This study highlighted the inconsistent use of methods in the health economic analysis of factorial trials. Few studies have compared methods for the analysis of factorial trials. One study found that the different methods led to different conclusions [9], whilst the other found that choice of method did affect the conclusions of the study. However, the degree to which the intervention was considered cost-effective varied with the different approach i.e. the probability of the intervention being cost-effective differed with the various approaches [11].

Further research is still required in order to evaluate the impact of alternative methods on policy recommendations and establish good practice guidelines on the design and economic analysis of factorial trials. Until a consensus is reached with respect to the economic analysis of factorial trials, it is suggested that researchers should test for interactions in economic outcomes before deciding on the primary analysis and explore alternative approaches in a secondary analysis. This can be achieved by using a regression approach, which can easily be adapted to take the form of a within-the-table or atthe-margins approach by either including or excluding an interaction term in the regression model 
[29]. When such interactions are unlikely to appear, the reasons should be explicitly stated. Such an approach will potentially ensure that the economic and other benefits of factorial trials are not translated into suboptimal policy recommendations.

\section{EXPERT COMMENTARY}

In an increasingly resource constrained environment, there is growing interest in employing factorial designs, which assess two or more interventions simultaneously using various combinations of the interventions within the same trial. Although methods for the analysis of clinical endpoints alongside factorial trials are well established, there is limited methodological guidance for the economic analysis. Most published economic evaluations assume no interaction between interventions and are inconsistently reported. Overlooking potential interactions on cost and outcome data may introduce bias and result in suboptimal policy recommendations. Further work is required to evaluate the impact of alternative methods on results from cost-effectiveness analyses alongside factorial trials.

\section{FIVE YEAR VIEW}

The increasing pressures on health care and research budgets are likely to be associated with an increase in the use of factorial trials and a corresponding increase in economic evaluations conducted along such trials. With the limited guidance available, it is expected that the inconsistent use of methods in the health economic analysis of factorial trials will continue. However, with the publication of additional studies highlighting the issues surrounding the economic analysis of factorial trials and the potential policy implications, there would be an increased awareness amongst resarchers. We expect to see more research comparing alternative analytical approaches and hope that this would lead to an increase in the development of methods and guidance for the economic analysis of factorial trials over the next five years.

\section{KEY ISSUES}


- There is a growing interest by health economists in employing factorial trials when analysing economic data in trial-based economic evaluations. However, methods for the economic analysis of factorial trials remain unclear and there seems to be limited guidance on which method is the most appropriate and under which circumstances.

- The results from this study showed that two different methods: 'within-the-table' and 'at-themargins' approaches were used for the analysis. However, with the exception of one study, all others did not consider interactions in costs and outcomes or give a detailed explanation of why a particular approach was adopted.

- This review found that although there was consistency in the application of general principles for conducting economic evaluations, there was lack of agreement with respect to methods for the economic analysis of factorial trials.

- Further research is required in order to evaluate the impact of alternative methods on policy recommendations and establish good practice methods on the design and economic analysis of factorial trials.

\section{REFERENCES}

1. Philips, Z., Ginnelly, L., Sculpher, M., Claxton, K., Golder, S., Riemsma, R., Woolacott, N. and Glanville, J. Review of guidelines for good practice in decision-analytic modelling in health technology assessment Health Technol Assess 2004;8:1-158

2. Petrou, S and Gray, A. Economic evaluation alongside randomised controlled trials: design, conduct, analysis and reporting. BMJ 2011;342: d1548

3. Johnston, K., Buxton, M.J., Jones, D.R. and Fitzpatrick, R. Assessing the costs of healthcare technologies in clinical trials Health Technol Assess 1999;3:1-73 
4. Couper, D.J., Hosking, J.D., Cisler, R.A., Gastfriend D. R. and Kivlahan, D.R. Factorial Designs in Clinical Trials: Options for Combination Treatment Studies. J Stud Alcohol Drugs $2005 ; 15: 24-32$

5. Morris, S., Morris, T.P., McGregor, A.H., Dore, C.J. and Jamrozik, K. Function After Spinal Treatment, Exercise, and Rehabilitation. Spine 2011;36:1807-1814

6. Xiang, A.H., Santher, H.N. and Azen, S.P. Power Considerations for Testing an Interaction in a $2 \times$ K Factorial Design with a failure Time outcome. Control Clin Trials 1994;15:489-502

7. Green, S., liu, P. and O’Sullivan, J. Factorial Design Considerations. J Clin Oncol $2002 ; 20: 3424-3430$

8. Brittain, E. and Wittes, J. Factorial designs in clinical trials: the effect of non-compliance and subadditivity. Stat Med 1989;8:161-171

9. Dakin, H., Gray, A., Fitzpatrick, R., MacLennan, G., and Murray, D. Rationing of total knee replacement: a cost-effectiveness analysis on a large trial data set BMJ Open 2012, doi:10.1136/bmjopen-2011-000332

10. Dakin H, Gray A. Economic evaluation of factorial randomised controlled trials: why the method of analysis matters. Health Economist Study Group 2010. http://hesg.org.uk/papers (Last accessed 14/8/2013).

11. Oppong, R., Jowett, S, Nicholls E et al, Joint protection and hand exercises for hand osteoarthritis: an economic evaluation comparing methods for the analysis of factorial trials. Rheumatology 2014;113:1-8

12. Centre for Reviews and Dissemination University of York. Systematic reviews: CRD's guidance for undertaking reviews in health care. Centre for Reviews and Dissemination, University of York, 2009. Available from: http://www.york.ac.uk/inst/crd/pdf/Systematic_Reviews.pdf

13. Dangour, A.D., Albala, C., Allen, E., Grundy, E et al, Effect of a nutrition supplement and Physical Activity Program on Pneumonia and Walking Capacity in Chilean Older People: A Factorial cluster randomised trial. PLOS Medicine 2011;8:1-12 
14. The UK BEAM Trial team, United Kingdom exercise and manipulation randomised trial: Cost effectiveness of physical treatments for back pain in primary care BMJ 2004;329:1381

15. Barton, G.R., Sach, T.H., Jenkinson, C., Doherty, M., Avery, A.J. and Muir, K.R. Lifestyle interventions for knee pain in overweight and obese adults aged $\geq 45$ : economic evaluation of randomised controlled trial BMJ 2009; 339: b2273

16. NICE, Guide to the methods of technology appraisal [ONLINE]. Available from http://www.nice.org.uk/media/B52/A7/TAMethodsGuideUpdatedJune2008.pdf 2008, (Last accessed 17/9/2013)

17. Thomas, K.S., Miller, P., Doherty, M., Muir, K.R., Jones, A.C. and O’Reilly, S.C. Cost Effectiveness of a Two-Year Home Exercise Program for the Treatment of Knee Pain. Arthrit Care Res 2005;53:388-394

18. Hollinghurst, S., Sharp, D., Ballard, K., Barnett, J., Beattie, A., Evans, M et al, Randomised controlled trial of Alexander technique lessons, exercise, and massage (ATEAM) for chronic and recurrent back pain: economic evaluation BMJ 2008;337: a2656

19. Boyle, J., McCartney, E., Forbes, J. and O'Hare, A. A randomised controlled trial and economic evaluation of direct versus indirect and individual versus group modes of speech and language therapy for children with primary language impairment. Health Technol Assess $2007 ; 25: 1-139$

20. McBeth, J., Prescott, G., Scotland, G., Lovell, K., Keeley, P. et al, Cognitive Behaviour Therapy, Exercise, or Both for Treating Chronic Widespread Pain. Arch Intern Med 2012;172: 48-57

21. Waterhouse, J.C., Walters, S.J., Oluboyede, Y. and Lawson, R.A. A randomised $2 \times 2$ trial of community versus hospital pulmonary rehabilitation for chronic obstructive pulmonary disease followed by telephone or conventional follow-up. Health Technol Assess 2010;14:1164

22. Pinto, D., Robertson, M.C., Abbott, J.H., Hansen, P. and Campbell, A.J. Manual therapy, exercise therapy, or both, in addition to usual care, for osteoarthritis of the hip or knee. 2: 
economic evaluation alongside a randomised controlled trial. Osteoarthr Cartilage $2013 ; 21: 1504-1513$

23. Campbell, A.J., Robertson, M.C., La Grow, S.J., Kerse, N.M., Sanderson, G.F. Jacobs, R.J., Sharp, D.M. and Hale, L.A. Randomised controlled trial of prevention of falls in people aged $\geq 75$ with severe visual impairment: the VIP trial BMJ 2005;331: 817

24. Jafar, T.H., Islam, M., Bux, R., Poulter, $\mathrm{N}$ et al, Cost Effectiveness of Community Based Strategies for Blood Pressure Control in a Low income Developing Country: Findings from A Cluster Randomized Factorial Controlled Trial. Circulation, 2011;124:1615-1625

25. Lindgren, P., Buxton, M., Kahan, T., Poulter, N.R. et al, The Lifetime Cost Effectiveness of Amlodipine-Based Therapy Plus Atorvastatin Compared with Atenolol Plus Atorvastatin, Amlodipine-Based Therapy Alone and Atenolol-Based Therapy Alone. Pharmacoeconomics, $2009 ; 27: 221-230$

26. Effing, T., Kerstjens, H., Van der Valk, P., Zielhuis, G. and Van der Palen, J. Costeffectiveness of self-treatment of exacerbations on the severity of exacerbations in patients with COPD: the COPE II study. Thorax, 2009;64:956-962

27. Lewycka, S., Mwansambo, C., Rosato, M., Kazembe, P. et al, Effect of women's groups and volunteer peer counselling on rates of mortality, morbidity, and health behaviours in mothers and children in rural Malawi (MaiMwana): a factorial, cluster-randomised controlled trial. Lancet, 2013;381:1721-1735

28. Bakai, A., Stone, G.W., Grines, C.L., Murphy, S.A, Githiora, L et al, Cost-effectiveness of coronary stenting and abciximab for patient with acute myocardial infarction: results from the (CADILAC TRIAL). Circulation, 2003;108: 2857-2863

29. McAlister, F.A., Straus, S.E., Sackett, D.L. and Altman, D.G. Analysis and Reporting of Factorial Trials: A Systematic Review. JAMA 2003;289:2545-2553

30. Montgomery, A.A., Peters, T.J. and Little, P. Design, analysis and presentation of factorial randomised controlled trials. BMC Med Res Method, 2003;3:26-30

31. Briggs, A. Economic evaluation and clinical trials: size matters. BMJ 2000;321:1362-1362 
32. Salmon, J., Arundell, L., Hume, C., Brown, H., Hesketh, K et al, A cluster-randomized controlled trial to reduce sedentary behaviour and promote physical activity and health of 8-9 year olds: The Transform-Us! Study. BMC Public Health, 2011;11:759-773

33. Nuffield Trust: Economic Evaluation and Health Care [ONLINE]. Available from http://www.nuffieldtrust.org.uk/sites/files/nuffield/publication/Economic-Evaluation-andHealth-Care.pdf (1998) (Last accessed 18/9/2013)

34. NICE, Methodology Checklist: economic evaluations [ONLINE]. Available from http://www.nice.org.uk/media/633/71/The_guidelines_manual_2009_Appendix_H_Methodology checklist__economic evaluations. pdf (2009) (Last accessed $17 / 9 / 2013)$

35. Evers, S., Goossens, M., de Vet, H., van Tulder, M. and Ament, A. Criteria list for assessment of methodological quality of economic evaluations: Consensus on Health Economic Criteria. Int J Technol Assess Health Care 2005;21:240-245

36. O'Brien, B. and Sculpher, M. 'Extended dominance in cost-effectiveness decision rules: Fine in principle but ...’ Med Decis Making, 1998;18:488-488

37. ISPOR, Guidelines on Health Economic Evaluation: Consensus paper. [ONLINE]. Available from http://www.ispor.org/peguidelines/source/Guidelines_Austria.pdf (2006) (Last accessed $18 / 9 / 2013)$ 